\title{
TREE-RING FEATURES: INDICATORS OF EXTREME EVENT IMPACTS
}

\author{
Achim Bräuning ${ }^{1, *}$, Maaike De Ridder ${ }^{2}$, Nikolay Zafirov ${ }^{3}$, \\ Ignacio García-González ${ }^{4}$, Dimitar Petrov Dimitrov ${ }^{5}$, and Holger Gärtner ${ }^{6}$ \\ ${ }^{1}$ Institute of Geography, University of Erlangen-Nuremberg, Wetterkreuz 15, \\ 91058 Erlangen, Germany \\ ${ }^{2}$ Wood Biology Service, Royal Museum for Central Africa, Leuvensesteenweg 13, \\ 3080 Tervuren, Belgium \\ ${ }^{3}$ Department of Plant Pathology and Chemistry, University of Forestry, 1756 Sofia, Bulgaria \\ ${ }^{4}$ Departamento de Botánica, Universidade de Santiago de Compostela, Escola Politécnica Superior, \\ Campus de Lugo, 27002 Lugo, Spain \\ ${ }^{5}$ Forest Research Institute, Bulgarian Academy of Sciences, 132 Kliment Ohridski Blvd., \\ 1756 Sofia, Bulgaria \\ ${ }^{6}$ Swiss Federal Research Institute WSL, Zürcherstrasse 111, 8903 Birmensdorf, Switzerland \\ *Corresponding author; e-mail: achim.braeuning@fau.de
}

\section{ABSTRACT}

Wood anatomical features may be visible on the microscopic as well as on the macroscopic scale. While the former can often be quantified by detailed wood anatomical analyses, the latter are often treated as qualitative features or as binary variables (present/absent). Macroscopic tree-ring features can be quantified in terms of frequency, intensity, or classified according to their position within a tree ring, like intra-annual density variations (IADFs) in conifers or frost rings in earlywood or latewood. Although some of these tree-ring features, like e.g. missing rings or IADFs are often seen as anomalies, hampering dendrochronologists to perform proper crossdating of tree-ring series, many of these properties are formed under extreme environmental stress or heavy impact, and could mark these extreme events by the manifestation in the wood anatomical structures throughout the lifespan of trees. The described tree-ring features form discrete time-series of extreme events. For example, flood rings may be marked by lunar-shaped earlywood vessels or enlarged latewood vessels in ring-porous oaks. White earlywood rings and light rings indicate reduced cell wall thickness and lignification occurring in very cold years. Frost rings result from cambial cell death during abrupt cooling events in the growing season. Missing rings and IADFs are mainly caused by drought events. Characteristic variations in earlywood vessel size, shape, or number in ring-porous oak species are markers for flood events, defoliation, heat stress, or drought. Traumatic resin ducts may be triggered by a range of biotic or environmental stressors, including wounding, fires or mechanical factors. Reaction wood is indicative of mechanical stress, often related to geomorphic events. In many cases anatomical responses are unspecific and may be caused by different stressors or extreme events. Additionally, the sensitivity of trees to form such features may 
vary between species, or between life stages within one species. We critically evaluate the indicative value of different wood anatomical tree-ring features for environmental reconstructions.

Keywords: Missing rings, white rings, light rings, frost rings, flood rings, reaction wood, earlywood vessels, traumatic ducts, extreme events.

\section{INTRODUCTION}

Besides their width as expression of growth vigour, the macroscopic appearance of tree rings provides information about environmental conditions during or before the formation of the respective wood. During the past years, improvements of preparatory (e.g., Schneider \& Gärtner 2013; Gärtner et al. 2014) and image analysis techniques (e.g., von Arx et al. 2013) allow the quantitative assessment of many wood anatomical variables at the cellular level (Scholz et al. 2013) and at the tree-ring level (e.g., Fonti et al. 2010; Olano et al. 2013; Hetzer et al. 2014). However, some wood anatomical anomalies are markers of certain environmental triggers in a qualitative sense, meaning that either they cannot be meaningfully quantified (e.g., what is the "real" ring width of a wedging ring?), or that their quantitative measurement does not add significant information for their interpretation because the effect-response system of the tree does not respond in a mathematically defined or yet unknown way to the intensity of the triggering agent. Hence, only occurrence in the sense of presence or absence, and the frequency of the respective feature may be recorded. Nevertheless, some of these macroscopic tree-ring features have important ecological indicator value (Schweingruber 1996, 2007; Beeckman 2016; Tarelkin et al. 2016). Since they represent manifestation of more or less rarely occurring extreme impacts on trees, they form discontinuous time-series of discrete events.

In the following, we summarize the knowledge on some of the most prominent macroscopic tree-ring features and discuss their possible indicator value for extreme events occurring in a tree's environment that may have triggered the formation of wood anatomical anomalies. Many of the described phenomena actually only appear in parts of a tree ring, like within the earlywood, the latewood, or occur somewhere within the whole tree ring but leave other parts unaffected, like e.g. frost rings or intra-annual density fluctuations (IADFs). Hence, the position within the tree ring is a time marker of their formation within the growing season. Since IADFs are dealt with by De Micco et al. (2016a), we will not deal with these features in this paper. For the other macroscopic tree-ring features, their presence within a tree or tree ring, their geographic distribution, and possible causes will be discussed.

\section{Features in response to climatic stress}

\section{Missing rings and partly missing rings}

A missing ring (MR) is a tree ring that is partially or completely absent. Hence, its absence can only be identified by crossdating with complete tree-ring series (Leuschner \& Schweingruber 1996). Wilmking et al. (2012) distinguish three types of MRs: 

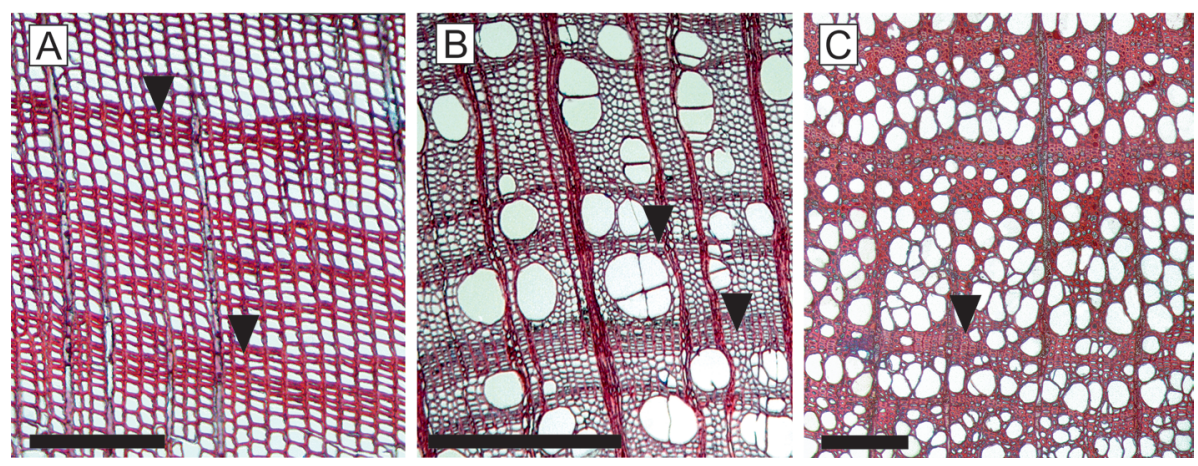

Figure 1.-A: Partially missing rings in Cupressus torulosa (Nepal). - B: Betula utilis (Nepal), and C: Fagus orientalis (Alborz Mountains, Iran). Arrows mark positions where tree-ring boundaries of consecutive rings are merging and the ring is wedging out. - Scale bars in A \& C represent $200 \mu \mathrm{m}$, in B $500 \mu \mathrm{m}$.

1) locally missing rings (LMRs), where one or more growth rings are missing in some part(s) of the plant (also called wedging rings); 2) totally missing rings (TMRs), where a plant does not produce wood anywhere along the circumference of the stem in a specific year, and 3) continuously missing outer rings at the stem base (CMORs). Most common are the LMRs or wedging rings (Fig. 1), a term that is also commonly used in texts on tree-ring anomalies (e.g., Worbes 2002).

All types of MRs can occur in a wide variety of species, growth forms and biomes, suggesting a general strategy of woody plant growth (Wilmking et al.2012). Although MRs, especially LMR, are quite commonly found in all forest types (Table 1), they often only represent $<1 \%$ of the total measured tree rings. More than half of the tree-ring records reviewed by St. George et al. (2013), i.e. 1296 of 2359 tree-ring records, did not show a single MR. This indicates that TMRs in stem wood are very rare. However, tree-ring series showing a high number of missing rings are often discarded from treering datasets due to dating problems, and hence there might be a bias towards tree-ring series that are still crossdatable. They can be for instance caused by extremely dry years (Novak et al. 2011, 2016).

While quantitative data on the frequency of MRs are more often available in temperate and boreal regions (Table 1), (L)MRs in tropical regions were reported for Podocarpus falcatus mountain forests in Ethiopia (Krepkowski et al. 2012), for Juniperus procera, Acacia spp. and Balanites aegyptiaca in dry tropical forests in Ethiopia (Wils et al. 2011), for Machaerium scleroxylon in Bolivia (Paredes-Villanueva et al. 2013), for Tectona grandis in East Timor (Sousa et al. 2012) and for Terminalia superba in a Congolese tropical forest (De Ridder et al. 2013). Worbes (2002) also provides a list of tropical tree taxa showing a tendency to form LMRs.

Generalizing the presence of MRs within a species should be regarded with caution. While early dendrochronological studies on Taxus baccata were abandoned due to a high frequency of missing rings (Lowe 1897), Galvin et al. (2014) succeeded in creating a tree-ring chronology without encountering any MRs. 
Table 1. Examples of the occurrence of missing rings in different tree species growing in a variety of environmental conditions.

$\mathrm{MR}=$ missing rings; $\mathrm{NA}=$ no data available.

\begin{tabular}{|c|c|c|c|}
\hline Species & $\% \mathrm{MR}$ & Suggested cause & Authors \\
\hline $\begin{array}{l}\text { Pinus banksiana and } \\
\text { Pinus sylvestris }\end{array}$ & $\begin{array}{l}\text { Up to } 40 \% \text { of tree rings during } \\
\text { years with severe outbreaks }\end{array}$ & $\begin{array}{l}\text { (Severe) outbreaks of jack } \\
\text { pine budworm the current or } \\
\text { previous year }\end{array}$ & Robson et al. (2015) \\
\hline Larix sibirica & $\begin{array}{l}\text { Only } 2 \% \text { of the total tree-ring } \\
\text { number }\end{array}$ & $\begin{array}{l}\text { Positive correlation with } \\
\text { frequency of hot days in June } \\
+ \text { drought during the growing } \\
\text { season }\end{array}$ & Khishigjargal et al. (2014) \\
\hline Tsuga heterophylla & $\begin{array}{l}30 \% \text { of tree rings during the } \\
\text { dry year begin } 1980 \text { s }\end{array}$ & $\begin{array}{l}\text { High number of consecutive } \\
\text { dry days and low sum of } \\
\text { precipitation }\end{array}$ & Glawenda et al. (2012) \\
\hline Juniperus communis & $<1 \%$ of total tree-ring number & $\begin{array}{l}\text { Very irregular shape of stems } \\
\text { with strip-bark growth form } \\
\text { in older individuals }\end{array}$ & Pellizzari et al.(2014) \\
\hline Juniperus tibetica & $\begin{array}{l}\text { Up to }>5 \% \text { total tree-ring } \\
\text { number }\end{array}$ & $\begin{array}{l}\text { Strip-bark growth form, dry } \\
\text { conditions in summer }\end{array}$ & Bräuning et al. (2001) \\
\hline Pinus halepensis & $19 \%$ of total tree-ring number & $\begin{array}{l}\text { Dry conditions from January } \\
\text { to May, high late winter to } \\
\text { spring temperatures }\end{array}$ & Novak et al. (2011) \\
\hline Pinus pinea & $10 \%$ of total tree-ring number & $\begin{array}{l}\text { Dry conditions from January } \\
\text { to May, high late winter to } \\
\text { spring temperatures }\end{array}$ & Novak et al. (2011) \\
\hline Pinus sp. & $0.8 \%$ of total tree-ring number & NA & St. George et al. (2013) \\
\hline Pseudotsuga sp. & $0.6 \%$ of total tree-ring number & NA & St. George et al. (2013) \\
\hline Larix sp. & $0.2 \%$ of total tree-ring number & NA & St. George et al. (2013) \\
\hline Larix griffithii & $0.2 \%$ of total tree-ring number & $\begin{array}{l}\text { Deep cooling of the cambium } \\
\text { by ice contact }\end{array}$ & Bräuning (2006) \\
\hline Picea sp. & $0.03 \%$ of total tree-ring number & NA & St. George et al. (2013) \\
\hline Quercus sp. & $0.01 \%$ of total tree-ring number & NA & St. George et al. (2013) \\
\hline Terminalia superba & $1 \%$ of tree-ring number per tree & NA & De Ridder et al. (2013) \\
\hline
\end{tabular}

Following the definition of Leuschner and Schweingruber (1996), missing rings are caused by lack of cambial activity due to extremely unfavourable growth conditions. Several causes are suggested but drought is most commonly met (Table 1) and caused, e.g., the widespread MRs in southwestern United States during the last millennium (St. George et al.2013). Increasing summer drought in Mongolia is also thought to have caused the repeated occurrence of missing rings in larch since the 1960s, thus MRs could act as an indicator of climate warming (Khishigjargal et al. 2014). Also in Europe, the wood formation of beech is strongly influenced by annual climate fluctuations but also by extreme events like heat waves (Ciais et al. 2005; Werf et al. 2007) and late frosts (Dittmar et al.2006), affecting cambial activity and therefore minimizing tree-ring widths. One example is the year 1953 caused by a late mid-May frost event 
followed by a very dry and hot summer in high-elevation beech stands. As a consequence of extreme drought, severe insect outbreaks were registered, also increasing the frequency of MRs (e.g., Pohl et al. 2006; Koprowski \& Duncker 2012; Robson et al.2015). Interestingly, the cambium as the key tissue for xylogenesis can be locally inactive for several years or even decades and then become active again. The cambium can be inactive in small parts of the stem or in the whole stem or only at the stem base (Wilmking et al. 2012).

Under dry tropical conditions, multimodal rainfall regimes are expected to increasingly cause missing rings in sensitive trees, as the wet seasons will often be too short to initiate tree growth (Wils et al. 2011). In tropical moist forests, temperature and rainfall are normally not limiting but buttressed roots can cause wedging rings in older trees that grow under poor light conditions and under competition (Worbes 2002).

At high-elevation sites in glacier forefields on the eastern Tibetan plateau, partly missing rings were found in Larix griffithii, probably as a result of deep cooling of the cambium by ice contact (Bräuning 2006).

Mann et al. (2012) hypothesized that MRs caused by large volcanic eruptions could question the reliability of the global tree-ring chronology network. However, this hypothesis was rejected by Esper et al. (2013) who used a compilation of maximum latewood density records, temperature records and documentary data from the European Alps and Northern Scandinavia to prove that there were no MRs after the large volcanic eruption of 1815. St. George et al. (2013) reviewed $>2300$ tree-ring records of the Northern Hemisphere and found that not all tree species form MRs.

Beside environmental causes, tree specific factors like tree age, tree architecture, social position within the forest, as well as local site conditions and sampling height have an impact on MR occurrence (e.g., Swetnam \& Lynch 1989; Lorimer et al. 1999; St.George et al.2013). No clear conclusion exists on the influence of tree age on MR frequency. In Mongolia, MRs were present in middle-aged and old trees in equal frequencies. However, the frequency of MRs appeared higher in the interior of the forest than at the edges where intraspecific competition for water between individuals is lower (Khishigjargal et al. 2014). In 55-year-old plantations of Terminalia superba, more MRs were found in the age class 20-30 years than in older age classes (De Ridder et al. 2013). Wilmking et al. (2012) found a clear correlation between MR frequency and age for a few of their studied species. The age of woody plants is possibly a factor influencing timing and duration of xylogenesis (Wilmking et al. 2012). For example, in three conifer species growing at the treeline in the Alps, the onset of cell production in older individuals in comparison with younger individuals was delayed, and total duration of cambial activity was shortened by two to three weeks (Rossi et al. 2008). However, it is difficult to distinguish age from tree size effects: at the end of the winter, larger stems with thicker bark remain colder for longer periods (Mayr et al. 2006), thereby delaying the start of temperature-dependent xylogenesis and contributing to an increase of MRs.

Another important concern is the sampling height, which is commonly set at breast height. Novak et al. (2011) sampled two pine species in Spain along their stems and found that the frequency of MRs gradually decreased from the bottom upward for 
Pinus halepensis, whereas no pattern was observed in P. pinea. Wilmking et al. (2012) studied 13 species at their distributional limits and generally found the same pattern of MRs as in P. halepensis. On the other hand, some studies reported a higher MR frequency in the upper parts of a stem, particularly in trees that have suffered sudden crown damage (e.g., Krause et al. 2003). In general, MRs occur mainly at lower stem portions where supply of auxins produced in the apical meristems and the decreased availability of carbohydrates might play a role in the non-formation of growth rings, especially in drought periods (McDowell et al. 2008).

The elevation of sample sites seems to be related to the formation of (L)MRs in beech stands. In the Balkan Mountains in Bulgaria, beech covers different altitudes from 600 to $1650 \mathrm{~m}$ a.s.l. At the upper elevation limit, we can expect higher sensitivity towards climatic factors. Dimitrov (unpubl. data) reveals that the incidence of LMRs in beech increases from low to high elevations. One possible explanation is the shorter vegetation period at $1650 \mathrm{~m}$. A longer vegetation period at lower elevations enables trees to overcome climatic stress factors and to form on average wider tree rings.

Local site conditions (floodway versus terrace forest) under a similar climate influenced the frequency of MRs for Pinus strobus trees (Michigan, USA). The frequency of MRs was generally greater on the terrace compared to the floodway forests, possibly related to the observed higher moisture stress in terrace forests during summer (Chhin et al. 2013). Missing rings were extremely uncommon at high latitudes; from $1 \mathrm{MR}$ on 240 present rings at moderate latitudes to $1 \mathrm{MR}$ on 2500 present tree rings at high latitudes (poleward of $50^{\circ} \mathrm{N}$ ).

Under different environmental conditions different factors can influence the formation of wood negatively and most likely, several factors act interlinked to produce MRs (Wilmking et al. 2012). Figure 1C shows one example from high elevation (1550 m a.s.1.) beech from Bulgaria (Dimitrov, unpubl. data). An overall dry year (1988), and cool spring and dry summer conditions in 1989, in combination with a short vegetation period at higher elevations most likely explain the formation of a LMR in 1989.

If MRs are the consequence of irregular stem shapes like lobate stem forms, stem disks should be sampled rather than increment cores. Multiple measurement paths are necessary but sometimes identification of rings is only possible on one direct or composite path. In the end, crossdating often remains problematic and it can happen that up to half of the disks are rejected to enter a chronology (see, e.g., Pellizzari et al. 2014 for Juniperus communis and McDougall et al. 2012 for Podocarpus lawrencei).

Apart from their disadvantages, MRs can be used as indicators for several phenomena. Rozas et al. (2011) used missing rings of Pinus canariensis to date past severe crown fires in the forests of Tenerife. An increased number of MRs can also help to predict impending tree mortality in conifers and, to this end, dendrochronology can help to record tree decline prior to visible signs of crown damage. This could be especially important in semiarid ecosystems at the distribution limits of many forest species (Novak et al. 2011). This was confirmed by St. George et al. (2013) who observed absent rings only in the southwestern United States but not in other Northern Hemisphere regions. Thus, future increases in the rate of MRs at other locations would indicate that forests are responding to unprecedented environmental stress. 
Independent evidence may come from the analysis of stable isotopes that may reveal seasonal variations of environmental conditions not bound to variations in anatomical wood structures (Krepkowski et al. 2012).
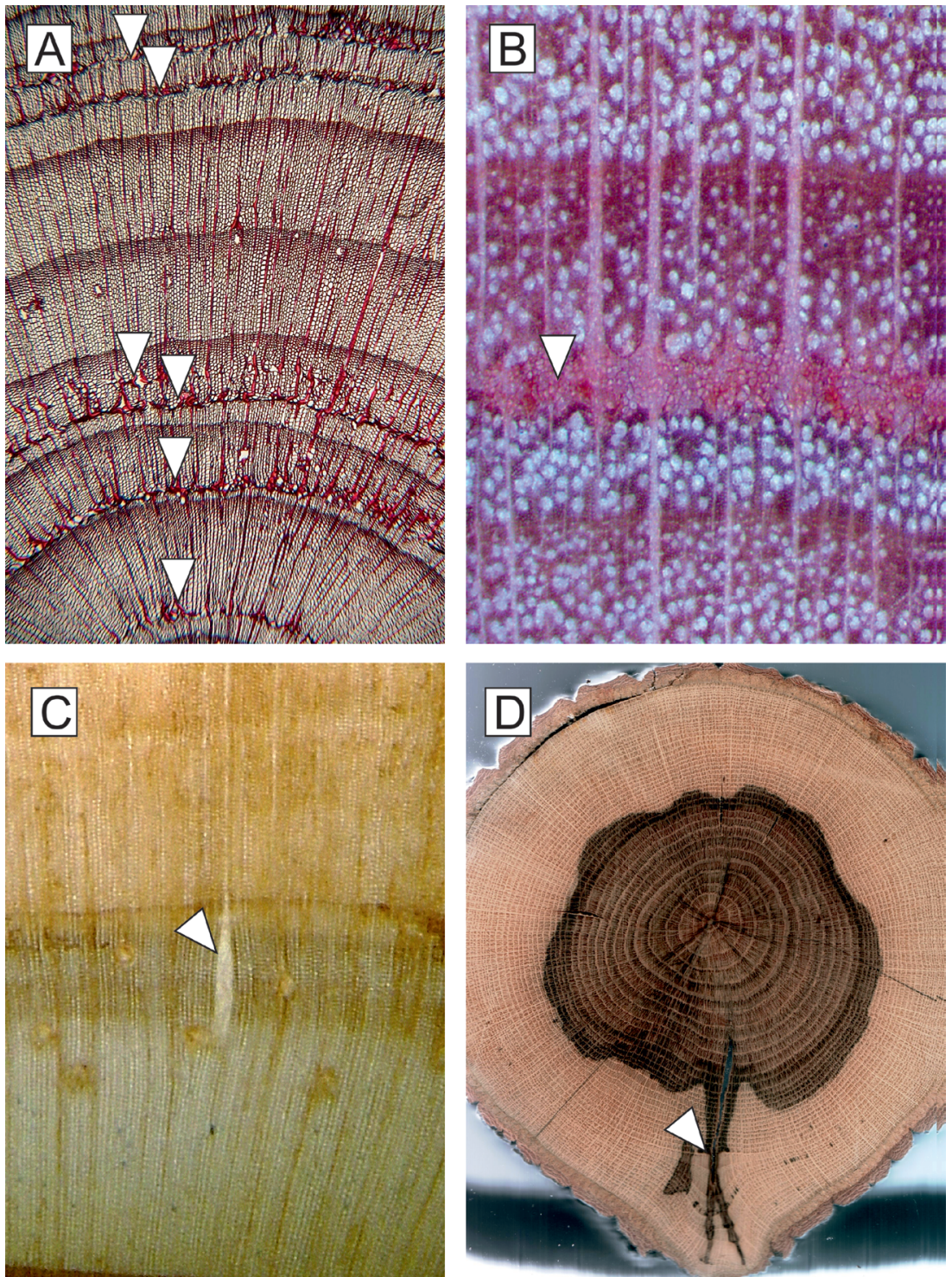

Figure 2. Frost rings (arrows) within Larix decidua (European Alps). - A: Some rings show multiple frost rings indicating occurrence of late frost and/or early frost events within one growing season. - B: Frost ring in Fagus sylvatica (Balkan Mountain range, Bulgaria). - C: Radial crack in Pinus sylvestris (Vitosha Mountain, Bulgaria). - D: Frost crack in Quercus and subsequent discolouration of sapwood and heartwood. The last tree-ring before frost crack formation is highlighted (arrow), it provides dating possibility for the event (Lakatos \& Mirtchev 2014). 


\section{Frost rings (FRs)}

Frost rings consist of a zone of unlignified, deformed tracheids, collapsed cells and traumatic parenchyma cells, and subsequently formed tracheids with irregular structure and orientation within a tree ring (Glerum \& Farrer 1966; Hantemirov et al. 2004) (Fig. 2A, B). FRs may be the most extreme form of wood anatomical imprints of temperature extremes. They are amongst the most studied anatomical markers which offer opportunities for drawing climatic information from tree rings (Wimmer 2002). Frost damage is caused by rapidly dropping temperatures below freezing during the growing season, when cambium is active and secondary wall thickening and lignification of immature xylem cells in the annual ring are not yet complete (LaMarche \& Hirschboeck 1984). Hence, FRs serve as a dendrochronological tool to reconstruct past occurrences of late and early frosts in frost-sensitive forest ecosystems (Hantemirov et al. 2004; Dy \& Payette 2007). From outside to inside of the stem, the phloem freezes first and shrinks, thereby compressing and deforming the delicate cells in the cambial zone (Sorauer 1922). The shrinkage is stronger in tangential than in radial direction and thus causes radial cracks or clefts. Day and Peace (1934), Glerum and Farrar (1966), and LaMarche and Hirschboeck (1984), however, state that freezing promotes extracellular ice formation and dehydration resulting in crushing of the outermost zone of weaker cells, leaving a permanent, anatomically distinctive record in the wood. They consider the dehydrating effect of freezing as more injurious to the cambium than the resulting physical pressure.

The position of the injury along the inner position of a tree ring is associated with frosts occurring in spring after initiation of cambial activity (Glock 1951; LaMarche 1970; Fritts 1976). Frost injury near the outer boundary of the ring is associated with a freeze late in the growing season before the cambium becomes dormant. Fritts (1976) states that frost rings are less frequently found in the larger stems than in the small branches, probably because of the insulation by the thicker bark of larger trees, a later initiation of cambial activity, and an early growth cessation in portions of trees which are distant from the growing stem apex. Thus, frost rings may be less frequent in outer portions of larger stems, but this does not necessarily imply that frosts were less severe in more recent years. The outermost tree rings formed under the thin bark of young and short trees will be in the inner parts of a stem when these trees get older and higher, whereas the more sensitive zone of the stem with thin bark will move upwards. For example, Waito et al. (2013) found FRs in 7-40\% of all rings in Picea mariana trees studied in central Canada. FR frequency was highest in lower parts of the stems, when the trees were of less than $4 \mathrm{~m}$ height. At $16 \mathrm{~m}$ height of the stems, FRs were still detected in the innermost 20 rings of the trees (Waito et al. 2013).

Frost rings in subalpine Bristlecone pines (Pinus longaeva and P. aristata) in western USA were reported to occur with high coincidence with major volcanic eruptions over the past several thousand years (LaMarche \& Hirschboeck 1984). The damage of these events to the trees is linked to climatic effects of stratospheric aerosol veils on hemispheric and global scales.

Frost rings were also found in tree-ring series from other species (e.g. Picea abies and Pinus peuce) from high altitude locations in Bulgaria in southeast Europe (Panayotov 
2007; Panayotov \& Yurukov 2007). Along an altitudinal gradient on Vitosha Mountain in Bulgaria (Panayotov et al. 2013), FR frequency increased from c. $1 \%$ of all tree rings at low elevation sites to c. $3 \%$ at higher elevation sites, pointing to an increased influence of the temperature regime at the high-altitude sites. Most of the zones with traumatic cells were found at the beginning of the earlywood, which was explained by frost events recorded in the beginning of May at lower altitude sites or in the middle of May at higher altitudes (Panayotov et al. 2013). However, one layer of deformed cells was found within the earlywood and was linked with late frost which occurred on the $9^{\text {th }}$ of June, when the growing season had already started.

Concerning diffuse porous species, FRs in European beech (Fagus sylvatica) are marked by traumatic and distorted ray parenchyma (Fig. 2B). Dimitrov (unpubl. data) reported frost rings in F. sylvatica from the Balkan Mountains (Bulgaria). The traumatic cells formed within the earlywood of the tree ring of the year 1876 (Fig. 2B) is most likely caused by a very late frost event, but due to the lack of climate records for that year, other traumatic factors negatively affecting cambial activity cannot $a$ priori be excluded. However, the occurrence of late frost events do not automatically result in the formation of frost rings. Throughout the $20^{\text {th }}$ century, frost rings in beech stands in Bulgaria were not recorded, despite several years with well documented late frost events.

In ring-porous oaks, frost rings are manifested by collapsed or lunar-shaped vessels, disrupted rays, and abnormal parenchyma in the earlywood zone (Stahle 1990; Land et al.2015). Stahle (1990) mapped the frequency of frost rings in oak trees growing over the Southeastern USA that are caused by sudden cold air intrusions after mild winter temperatures and derived the risk of frost damage for cold-sensitive fruit cultures.

In summary, although frost rings may occur in all climatic or elevation zones with occasional temperatures below freezing, they do not indicate the exact temperature during a frost event. Instead, their formation requires as a predisposition a state of physiological "perceptiveness" of the tree which is the case after or before winter dehardening. Also, trees of different species may show differences in sensitivity to form FRs under identical climate conditions (Gurskaya 2014). As a consequence, frost rings do not allow a quantitative reconstruction of the exact temperature triggering their formation, but from their frequency, geographic occurrence and position within the tree ring they allow conclusions about the temporal and spatial distribution, and a close estimation of the timing of the frost event.

\section{Radial cracks}

Radial cracks are caused by internal stress in the wood, mainly by frost, drought, wind, or lightning (Knuchel 1947; Cherubini et al. 1997). These cracks are divided into two types: cracks limited within one single tree ring ("internal intra-annual type") (Fig. 2C), and the open type including a callous margin and overgrowing tissue (Fig. 2D). Although these anatomical features might provide information about past extreme events, they have rarely been investigated in a dendrochronological context, with most studies focusing on intra-annual radial cracks (Cherubini et al. 1997; Grabner et al. 2001; Grabner et al. 2006). 
The decisive effect of frost for the formation of cracks in wood has already been recognized by early forest scientists (Nördlinger 1878; Hartig 1896) and has since then been confirmed by more recent studies. Radial cracks or so-called frost cracks can occur at temperatures which induce the freezing of water in wood cell lumens (Cherubini et al. 1997). Although freezing water also increases its volume, this type of crack is mainly caused by the cold shrinkage of wood due to internal drying as a consequence of the freezing out of cell wall moisture into the lumens of wood cells. The tangential shrinkage is stronger than the one in a radial direction and leads to tangential tension strain, which triggers cracking (Kübler 1983). Drought may also induce cracks through tangential shrinkage due to water loss (Nordlinger 1878; Barrett 1958; Aigner 1981; Caspari \& Sachsse 1990; Booker 1994). Cracking behaviour models of trees influenced by wind stress have been developed by Peters et al. (1985) and Ossenbruggen et al. (1986).

Cherubini et al. (1997) performed a dendroclimatological study on the ecological significance of intra-annual radial cracks in live Norway spruce (Picea abies) sampled at two sites in the eastern Alps and isolated trees in the Swiss Jura. The authors suggested that cracking is caused by winter desiccation. These water imbalances occur in early spring when the needles are warmed in sunny weather inducing high transpiration rates, but when soils are still very cold or frozen they do not allow water uptake by the roots.

Grabner et al. (2001) investigated intra-annual radial cracks in Norway spruce in southern Sweden. They found evidence that strong weather fluctuations - dry-wet cycles during the growing season, resulted in high internal mechanical tension strains due to tangential shrinkage that exceeded fracture limits of the wood. During such periods the tree rings from the previous year carried the highest load of tangential and vertical tension forces, which triggered the creation of intra-annual radial cracks starting from the middle lamella of two earlywood tracheids or between tracheids and ray parenchyma (Grabner et al. 2006 and references therein).

Grabner et al. (2006) studied the induction of radial cracks in living trees and found that tree rings characterized by very low earlywood density are predisposed for the formation of cracks. Strong summer droughts induced wood desiccation and the resulting tension initiated the formation of cracks reaching into the previously formed low-density ring. Since the cracks are filled with resin but do not show signs of traumatic tissue, they must have been formed in the sapwood but outside the cambial zone (Grabner et al. 2006). Radial cracks do not occur in the outermost tree ring, but one to three tree rings away from the cambium, hence they cannot be used to date drought events at an annual resolution.

The open type of radial cracks with callous margin and overgrowing tissue is mainly caused by early spring frosts, or occasionally by late fall frosts. These frosts induce abnormal shrinkage of the sapwood when a stem that was warming during the day is affected by quick cooling and shrinkage of the outer parts of the stem during cold nights (Fig. 2D; Lakatos \& Mirtchev 2014). This type of damage is characterized by vertical cracks in the main stem that can extend over more than 10 metres. Frost cracks are usually seen in older trees, especially of oak species. These radial cracks are important 
from a phytopathological point of view, because they act as entry points for canker inducing micro-organisms, for example Nectria canker (Lakatos \& Mirtchev 2014), and wood-decaying fungi or can lead to stem breakage.

\section{Light rings (LRs)}

Light rings (LRs) occurring in conifer wood are characterized by one or very few layers of latewood cells of reduced cell wall thickness (Liang et al. 1997; Gindl 1999), wood density (Wang et al.2000), and lignin content (Gindl \& Grabner 2000), and hence they appear as rings with a usually narrow band of less dark latewood cells (Filion et al. 1986; Wang et al.2002), therefore also being termed 'pale latewood rings' (Waito et al.2013). Recently, rings with bands of incompletely or non-lignified secondary cell walls were described from high-elevation sites in the Italian Apennines in Pinus nigra. Due to their blue appearance in safranin-astrablue died thin sections, they have been introduced as "blue rings" (Piermattei et al.2015) and were assigned to exceptionally low temperatures in the late growing season suppressing lignification. To which degree "blue rings" are another representation of LRs identified by using a different detection method remains to be tested.

LRs can be defined visually or by relative densitometric thresholds, and both methods lead to comparable results, at least when the reduction of latewood is pronounced (less than 2 standard deviations from mean latewood; Wang et al. 2000). Their occurrence is generally independent of ring width and tree age (Filion et al. 1986; Gindl 1999; Wang et al. 2002). In comparison with cell wall variables like cell wall to lumen ratio, $\mathrm{X}$-ray density profiles indicate light rings more clearly (Wang et al. 2002) which may also be caused by reduced lignin content in light ring latewood cells (Liang \& Eckstein 2006).

LRs are reported from various conifer species and increase in frequency towards treeline positions at high latitudes or in subalpine environments, where latewood formation and especially its cell wall differentiation is closely correlated to summer or autumn temperature during a short growing season (Filion et al. 1986; Delwaide et al. 1991; Gindl et al. 2000; Wang et al. 2000, 2002; Tardif et al. 2011; Piermattei et al. 2015). In the polar Urals, LR frequency in Larix sibirica and Juniperus sibirica amounted $0.2 \%$ and $13.5 \%$, respectively (Hantemirov et al. 2004). Hence, LRs occur in years with reduced spring, summer, or autumn temperature, although not every cold year triggers LR formation (Gindl 1999; Wang et al. 2000; Girardin et al. 2009), whereas precipitation does not have a great influence on LR formation (Szeicz 1996; Girardin et al. 2009). The percentage of trees at a site in a given year affected by LR formation is highly variable, but frequency can reach $>50 \%$ and increases toward the tree limit (Yamaguchi et al. 1993; Szeicz 1996; Gindl 1999; Wang et al. 2000). Nevertheless, LRs are good markers for cold conditions during the growing season if they exceed a threshold of c. $5 \%$ and often occur synchronously over larger areas (Delwaide et al. 1991; Yamaguchi et al. 1993; Szeicz 1996). In interior North America, LRs occur at almost $30 \%$ of all years since the early $18^{\text {th }}$ century (Girardin et al.2009). Their occurrence in boreal Canada has been associated with volcanic eruptions, but LRs may show a lagged response to a volcanic event of 1-2 years (Filion et al. 1986; Yamaguchi et al. 
1993; Szeicz 1996; Briffa et al. 1998). Although LRs occur more frequently than FRs, they can occur synchronously (e.g., Hantemirov et al. 2004). From the occurrence of narrow and light rings (although not explicitly called so in their publication) discovered in subfossil pine trees found in northern Switzerland, Friedrich et al. (1999) were able to date the prehistoric explosion of the Laacher Lake volcano in central Europe. In contrast to boreal climates, LR formation in Chinese pine growing in semiarid northwest China often co-occurs with narrow rings and was caused by drought in autumn of the prior growth year and dry summers (Liang \& Eckstein 2006).

A similar phenomenon as climatically induced LRs can be caused by insect defoliation, as has been described for deciduous larch species, like e.g. Larix laricina in Canada (Liang et al. 1997) and L. decidua in the European Alps, but in many cases the LR is embedded in a typical pattern of a sequence of abnormal rings (Weber 1997) that can help to distinguish it from climatically induced LRs.

LRs were only described from conifer wood, although narrow and light latewood may also occur in hardwood species (e.g. Fagus orientalis, Pourtahmasi et al. 2011), but it is not explicitly called 'light ring' and and is caused by other factors.

\section{White rings (WRs) and white earlywood rings (WERs)}

WERs have been described from various conifer species growing in the boreal zone of Canada. They are characterized by bright appearing earlywood. In Picea mariana, cell wall thickness of earlywood tracheids was $11 \%$ thinner than in control rings (Waito et al. 2013). Lumen diameter of latewood in WERs was also $15 \%$ smaller. A possible reason for WER formation is carbon depletion due to defoliation or lack of phytohormones (Hogg et al. 2002; Sutton \& Tardif 2005). WERs occurred in 5-17\% of all rings, in some years co-occurring with FRs. A possible explanation may be reserve depletion after severe frost damage of needles and buds (Waito et al. 2013). Along tree stems, WERs are rather evenly distributed but were absent in the upper few metres of a stem, where frost rings were more frequently occurring in the year predating a WER, possibly pointing to a carbohydrate depletion after frost-induced needle damage.

WERs often occurred synchronously in multiple species over wide geographic scales of up to $1000 \mathrm{~km}$. They were rather evenly distributed throughout the stems but were missing in the upper few metres of the stems, where growth hormone concentrations are higher than near the stem base (Waito et al. 2013).

In hardwood species like Populus tremuloides, WRs consist of fibres with smaller diameter and thinner cell walls and a reduced density of around $20 \%$ compared to normal rings (Hogg et al. 2002; Sutton \& Tardif 2005). They are the probable analogue to conifer WERs (Waito et al.2013) and seem to be caused by similar ecological factors.

\section{Earlywood anomalies in ring-porous species}

Several characteristics of the earlywood vessels of ring-porous oak trees (size, number, and/or distribution) vary across sequences of tree rings (Fig. 3A), and have been recently used to obtain time series, as they appear to contain valuable environmental information (Fonti et al. 2010; García-González et al. 2016). However, year-to-year variation in earlywood appearance is small and extreme values in time series of ear- 
lywood features rare. Hence, it is not straightforward to identify earlywood markers (e.g., remarkably anomalous vessel size or number of vessels). This is probably the reason why these features have received little attention. Schweingruber et al. (1990) suggested the size of earlywood vessels as one of the characteristics that should be observed to identify pointer years in dendrochronology, whereas Leuschner et al. (1996) proposed a method to classify some of them. The number of studies that illustrate these features in ring-porous trees is scarce (Priya \& Bhat 1998; Schweingruber 2007), which contrasts with the attention other tree-ring features received, for example IADFs (e.g., De Micco et al. 2014, 2016a).
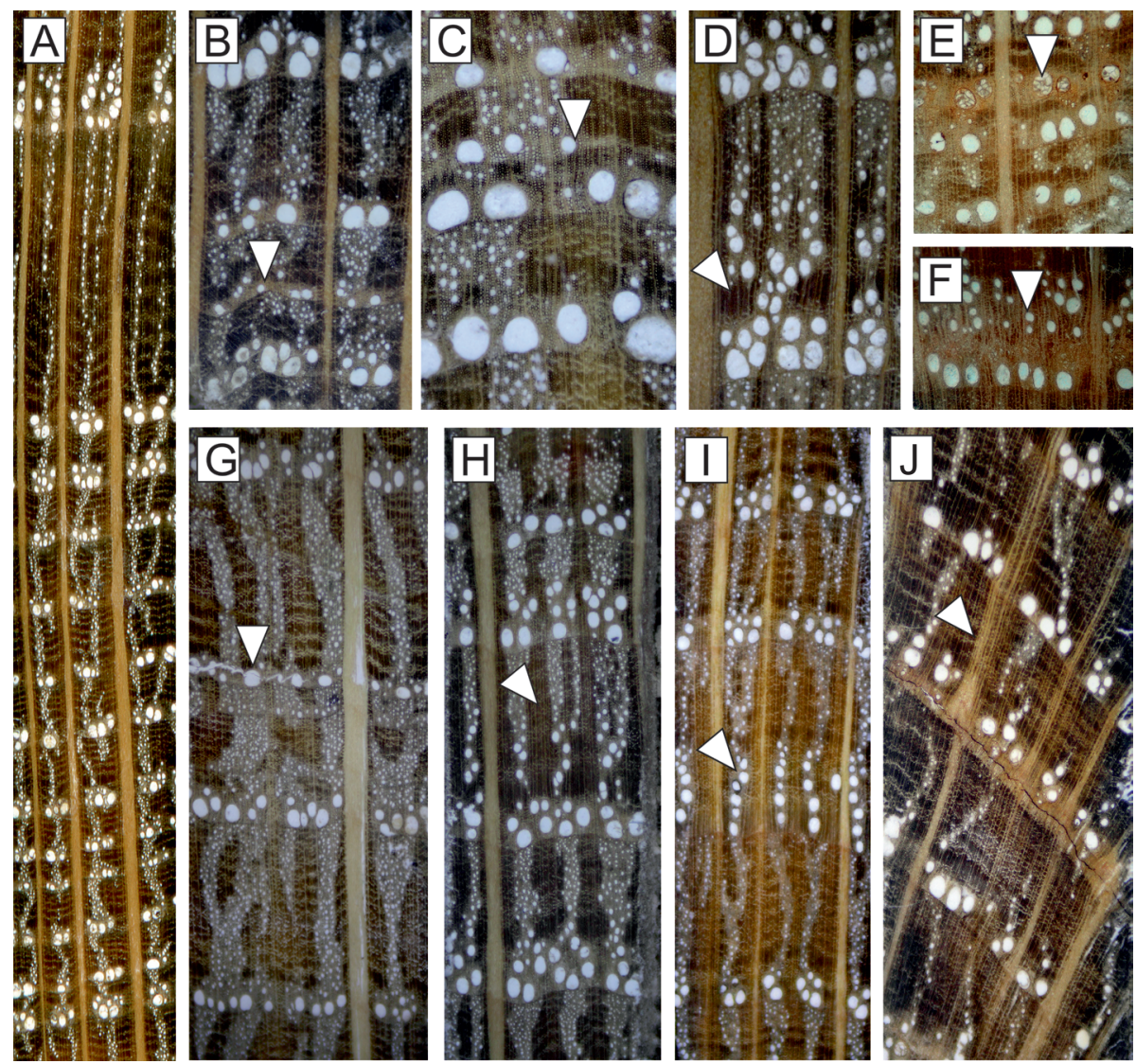

Figure 3. Special features in ring-porous oaks (Quercus sp.). - A: Variation of size, number, and/or distribution of earlywood vessels of ring-porous oak trees in different tree rings. - B: Ring with reduced earlywood vessel diameter (arrow). - C: Ring with narrow latewood followed by rings with small and few earlywood vessels (arrow). - D: Ring with complex of fibres without vessels in transitional zone from earlywood to latewood (arrow). -E: Set of few rings with tyloses within sapwood (arrow) indicating a traumatic event. - F: Double ring (arrow). - G: Latewood ring with smaller earlywood vessels (arrow). $-\mathrm{H}$ : Very wide rings after a growth release with large complexes of fibres (arrow). - I: Rings with earlywood vessels aligned in radial rows (arrow). - J: Modified rays after cambial wounding (arrow). 
The frequency of rings with exceptional earlywood is rather low, but any deviation from the usual wood anatomical appearance, i.e. rings that are clearly different from the surrounding ones should always be considered (i.e., ring with only one row of vessels in a sequence of rings with two or more rows of vessels, abnormally large or small vessels, peculiar vessel distribution, etc.) as a potential source of environmental information. Very often, only a minority of trees at a site presents peculiar earlywood, but the characteristic may be widespread over many sites. These features usually assist in crossdating difficult ring-width sequences when developing dendrochronological series. Some of the most common or significant groups of features are detailed in the following; for the sake of simplicity, they were classified into three heterogeneous groups, explaining the most common earlywood vessel variations: 1) features associated with small vessels; 2) features associated with exceptionally wide rings; 3) presence of traumatic tissue.

Rings with clearly smaller vessels are often observed across sequences of tree rings (Fig. 3B). Sometimes only vessel size differs from the surrounding rings, whereas vessel number or distribution can be involved in other cases. Thus, very thin latewood is often followed by a ring with scarce and small earlywood vessels in the following year, as was the case for 1994 in northwestern Iberia (Fig. 3C); in such cases, crossdating is required to identify the presence of both rings.

Abundant small earlywood vessels in oak have been suggested as a marker for flooding events (Astrade \& Bégin 1997; St.George et al. 2002; Copini 2015). Recent experimental approaches have gained further insight in the formation process of "flood rings". Artificial flooding of at least two weeks provoked a reduction of earlywood vessel size of around 50\% in flooded parts of Quercus robur stems (Copini 2015). While the duration of flooding had no effect on flood ring formation, the timing of flooding had a strong impact on wood anatomy: if flooding occurred during earlywood formation, collapsed, lunar-shaped earlywood vessels in addition to many anomalously small vessels were formed. In contrast, floods that start and end during latewood formation result in a flood ring with anomalous large latewood vessels (Copini 2015). After three weeks of flooding, oaks formed enlarged traumatic latewood vessels (Land 2014). In softwoods like Taxodium distichum, tracheids in flooded stem parts are shorter, slightly wider, and had thinner walls than tracheids (Yamamoto 1992), whereas - in contrast - in Pinus pinaster, Ballesteros et al. (2010) found earlywood tracheids formed after flash floods to be reduced in lumen area about $38 \%$.

Regarding the spatial arrangement, ring-porous trees by definition form the largest vessels at the beginning of the season, and vessel size abruptly decreases in successive rows. Any distinguishable deviation from this pattern, i.e., the presence of a first row of smaller vessels, is a feature to be considered as a potential indicator of environmental information. In fact, García-González et al. (2003) associated the appearance of such a ring in oak (Fig. 3G) with very dry conditions at the moment of cambial resumption in 1990 in coastal areas of the northern Iberian Peninsula. Conspicuously small earlywood vessels in European oaks (Quercus robur) were associated with abnormally severe winters and cold springs (Fletcher 1975).

Very wide rings often show peculiar variations within the earlywood. For example, a conspicuous band with few or no vessels but with more intensively lignified fibres 
(Fig. 3D) could probably be associated with a warm and dry period during spring, while favourable conditions for the formation of earlywood in a specific year could result in a considerably higher number of vessel rows (Fig. 3I). It is also common that wide rings resemble juvenile wood (Helinska-Raczkowska 1994), even if occurring many years after the juvenile period. In the case of oaks, it is common to find radially-elongated vessels followed by a transitional area of large vessels arranged in radial rows (Fig. $3 \mathrm{H}$ ), and when affecting only very few rings within a sequence, they are often a marker of growth releases, for instance due to thinning.

Some features within the earlywood can also be of traumatic origin and affect both the axial and radial systems. These mainly involve the presence of tyloses, callus tissue, and/or abnormal vessels. The presence of tyloses in only a single or few rings within the sapwood (Fig. 3E) should be considered of great indicator value, especially if repeated in other parts of the tree, or across several individuals, because it is commonly a consequence of vascular dysfunction (Cochard \& Tyree 1990), and could consequently be related to damages as, e.g., an intense defoliation. De Micco et al. (2016b) review how vessel occlusions like tyloses or gum deposits are often induced by cavitation in the sapwood vessels. Callus tissue and distorted (lunar-shaped) vessels are often associated, and are produced by a strong disturbance during the early season (Fig. 3F); the tissue formed after the event is usually normal. One of the most common causes considered has always been late frost affecting cambial derivatives (Stahle 1990; see paragraph above on frost rings), which is mainly restricted to the youngest parts of the trees as the bark is thinner. But other events (e.g. intense defoliation by late frost or insect outbreaks immediately after bud burst), are also a feasible explanation, especially if found after the first vessel row; a 'double ring', i.e., the existence of a second ring of large vessels as a consequence of as second flushing, may also be present. Other anomalies may include the presence of undifferentiated cells in any part of the ring, the presence of compartmentalization, collapsed cells, or modified rays, and are often the result of cambial wounding (Fig. 3J).

\section{Features in response to mechanical stress or impact}

\section{Reaction wood}

The upright orientation of tree stems is basically controlled by a negative gravitropism of the apical meristem, forcing the stem to always grow against gravity. This results in an upright stem, no matter if the tree is growing on a flat plane or a steep slope (Tasaka et al. 1999; Morita \& Tasaka 2004). The centre of gravity in an upright stem is always balanced above the root collar to guarantee stability, since a tilted stem and continuous height growth will sooner or later shift the stem's centre of gravity upwards and finally reduce its stability, in extreme cases resulting in stem breakage or uprooting. As soon as trees are tilted by external forces or by mechanical stresses on the stems or crowns (e.g., by unstable ground, snow load, heavy wind stress or geomorphic processes), they counteract these forces by developing reaction wood (Sinnott 1952; Wardrop \& Dadswell 1955; Wardrop 1965; Côté \& Day 1965; Scurfield 1973; Wilson \& Archer 1977; Donaldson et al. 2004; Gardiner et al. 2014). The formation of reaction wood is related to gravitropic signals rather than being caused by compression or tension forces 
(Jaccard 1938; Raven et al. 1999; Gardiner et al.2014). As soon as a tree is moved out of its vertical position, reaction wood is formed on one side of the stem resulting in an eccentric shape of the rings (Bamber 2001; Wistuba et al. 2013). This eccentricity occurs on the lower side of the inclined plant part in coniferous trees (compression wood) and on the upper side (tension wood) in dicotyledonous trees. Reaction wood also plays a role in supporting a species specific tree architecture by maintaining the basic orientation of branches after mechanical strain due to external (e.g. snow load) or internal (e.g. size dependent weight) forces (Fisher \& Stevenson 1981; Brüchert \& Gardiner 2006).

Compression wood is recognizable macroscopically by its dark colour (Fig. 4A), and characterized by rounded tracheids (and therefore showing intercellular spaces) and
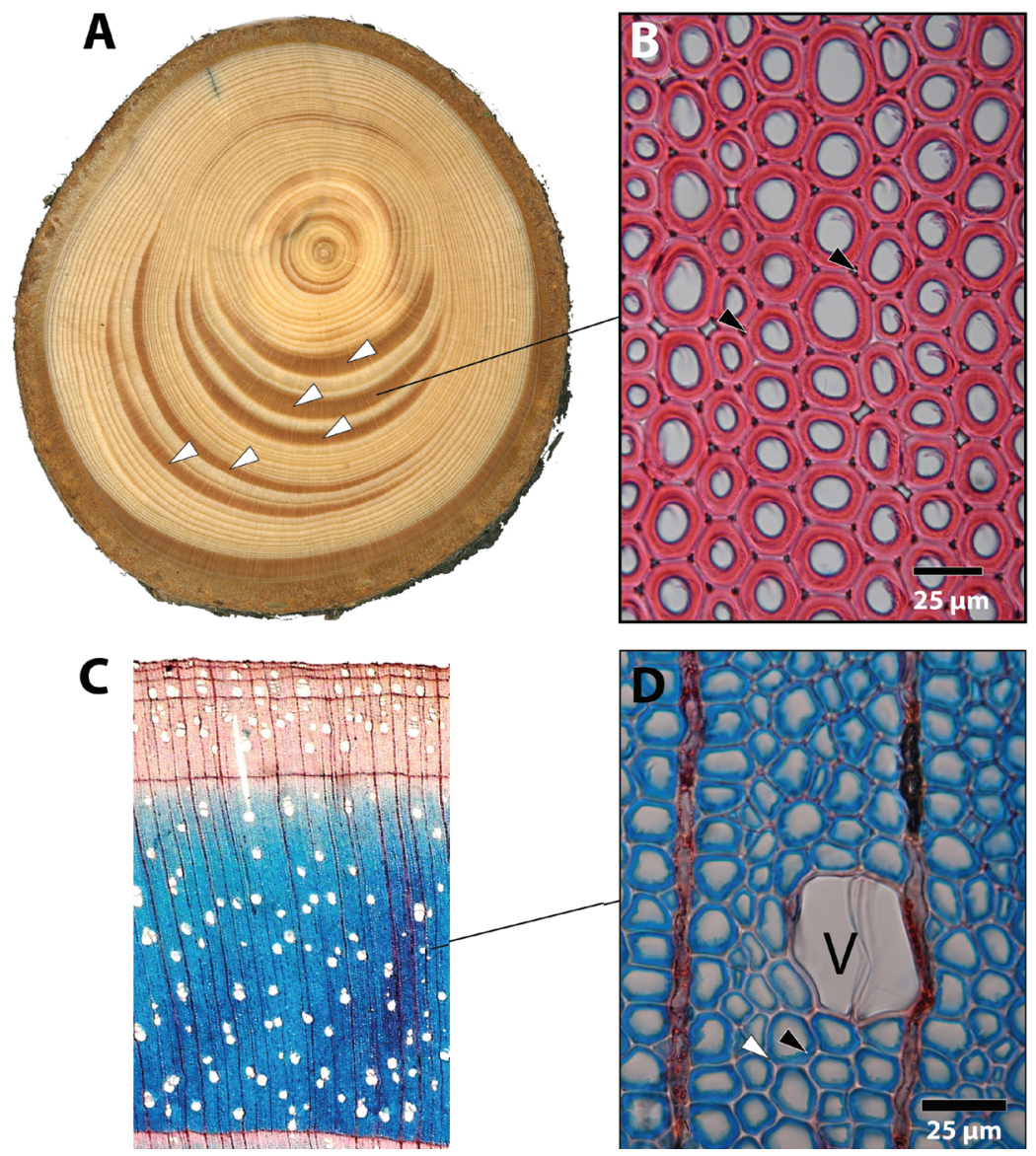

Figure 4. - A: Compression wood in a disc of Picea abies (white arrows). - B: Section showing the anatomical structure of compression wood, tracheids are rounded showing intercellular spaces (black arrows), the secondary walls are thick. - C: Very wide ring of Betula pendula showing tension wood (blue zone). - D: Detailed view of tension wood showing unlignified G-layers (gelatinous fibres in blue [stain: astrablue]; black arrow). The $S_{1}+S_{2}$ layers of fibre cell walls are thin and lignified (red [stain: safranin]; white arrow). $-\mathrm{V}=$ vessel. 
thick, highly lignified secondary cell walls with helical cavities and high microfibrillar angles (Timell 1986).

Tension wood is hardly visible macroscopically, which is an obstacle related to environmental analyses, especially in geomorphology (Gärtner \& Heinrich 2013), although it is usually credited with a silvery sheen (Côté \& Day 1965). Proper detection of tension wood requires microscopic inspection. Tension wood fibres are characterized by a gelatinous layer (G-layer) (Côté \& Day 1965; Coutand et al. 2004; Gärtner \& Heinrich 2013), which is unlignified and has highly crystalline microfibrils running nearly parallel to the fibre axis (Clair \& Thibaut 2001; Clair et al.2005; Abedini et al. 2015).

Field experiments revealed that the intensity of tension wood formation clearly has a negative impact on vessel size and number (Heinrich et al.2007), which is also indicating a shift from hydraulic towards mechanical functionality.

While several major monographic reviews of compression wood in gymnosperms exist (e.g., Westing 1965; Timell 1986; Gardiner et al. 2014), tension wood in angiosperms in general has been studied less (Gardiner et al. 2014). Therefore, there is a need to define and further analyse existing variability in the expression of tension wood, before it can be used as an ecological indicator (Clair et al. 2006; Fang et al. 2008).

Regarding ecological indicators, the occurrence of reaction wood as well as its multiple variations is frequently used to reconstruct geomorphic processes such as landslides, debris flows, avalanches, or even glacier fluctuations (e.g., Bräuning 2006; Butler \& Sawyer, 2008; Gärtner \& Heinrich 2013).

\section{Resin ducts}

Resin ducts (RDs) are an important part of the defence system of conifers to protect them against potential attacks of herbivores and pathogens (Nagy et al.2000). RDs are an aggregation of secretory and subsidiary cells and consist of epithelial cells producing the resin accompanied by parenchyma cells, building up a channel to which the resin is transferred. Wiedenhoeft and Miller (2002) named this system the "resin canal complex". They frequently occur in the xylem of most Pinaceae species (Richter et al. 2004) and can be regarded as passive protection as long as single ducts are randomly distributed within the xylem. The axial resin ducts, easily detectable in cross sections are connected to radially oriented resin ducts localized within the rays. Through these connections they form a three-dimensional network within the xylem (Gärtner \& Heinrich 2013). However, these ducts are not restricted to the xylem, they also occur in the phloem or the needles of a conifer (Evert 2006; Sheue et al. 2014).

All non-Pinaceae conifers (e.g., Taxaceae, Cupressaceae, Podocarpaceae, Araucariaceae) do not show this "passive" network in the regular xylem (Schweingruber 1996; Richter et al.2004), but only form resin ducts in case of a damage to the cambium by insect attacks or mechanical wounding. Surviving cambial cells adjacent to the disturbance start producing dense, tangentially oriented row(s) of resin ducts surrounding the wounded area (Nagy et al.2000), which can be seen as an "active" defence system. The occurrence of traumatic tangential rows of resin ducts is always an indicator for any kind of disturbance exerted to the cambium, as e.g. by insect attacks or mechani- 
cal wounding of the tree (Schweingruber 2007). The timing of their formation after a disturbance can be seen as crucial when aiming to reconstruct, e.g., recurrence intervals of avalanches or debris flows (Gärtner \& Heinrich 2009; 2013). This time lag was analysed using various techniques, e.g. by directly spraying methyl jasmonate on needles to trigger the formation of resin ducts (Martin et al.2002), or by experimental wounding during the vegetation season (Christiansen et al. 1999). Nevertheless, the response time of the formation of traumatic rows of resin ducts after mechanical wounding is species specific and also depends on the timing of the impact (Gärtner \& Heinrich 2009). Therefore, a precise dating of mechanical disturbances using traumatic rows of resin ducts is not possible without the presence of additional indications as, e.g., compression wood or growth reductions, nor can the trigger be quantified in terms of physical units of force or its nature without further evidence (e.g., wind speed after wind damage or the magnitude of debris flow events or avalanches).

\section{CONCLUSION AND PERSPECTIVES}

If macroscopic or microscopically detectable tree-ring features occur synchronously, they can support dendrochronological crossdating between tree individuals of a stand or even region (e.g., Filion et al. 1986). However, although the described macroscopic tree-ring features represent clearly distinguishable and recordable anomalies of the wood anatomical structure of trees, several open questions remain and practical issues are to be resolved before full use can be made of their indicator value.

Problems for analysing macroscopic wood anatomical features arise from the fact that they are often only formed or visible in parts of a tree stem (e.g., reaction wood, flood rings), or their distinctness and intensity may vary within one individual. Mostly, they are only present in a portion of tree individuals at a site. In addition, some wood anatomical features are often not independent, but may be intercorrelated (Wimmer 2002). Hence, sampling strategies for analyzing wood anatomical features need to be adapted to the specific research question. Since many anatomical features are not formed in all trees of a site, the sample number often needs to be higher than for dendrochronological studies to achieve a statistically robust sample number. Wilmking et al. (2012) and Novak et al. (2011) recommend the application of serial sectioning for wood species growing in hostile environments. Pinning experiments covering the whole length of the stem may provide better insights into the phenomenon of MR formation concerning hormone transport and cambial activity.

The identification of certain macroscopic tree-ring features like, e.g., LRs or WERs, is based on experience and expert knowledge; hence there may be a risk that the frequency of some features are underestimated by individual researchers just using visual detection approaches. Quantitative wood anatomical analysis, which becomes more and more a semi-automatic routine process with more powerful image analysis tools (e.g., von Arx et al. 2013; von Arx \& Carrer 2014) may be useful in defining objective thresholds for the detection of some of the respective features.

Some wood anatomical anomalies like e.g. frost rings or light rings are very specific in terms of the triggering agent, whereas other features like e.g. missing rings or 
traumatic resin ducts are unspecific and may be caused by different environmental factors. Hence, to interpret them correctly, additional anatomical, chemical, morphological, ecological, geographical, or historical information is needed. Refined wood anatomical characteristics may help in the future to distinguish sub-types of macroscopic wood anatomical features and assign their formation to more specific environmental factors. New statistical tools like, e.g., coincidence analysis (Donges et al. 2015) may further help to disentangle different climatic triggers leading to uniform tree-ring responses, and non-linear statistics like multivariate adaptive regression splines (MARS) may prove helpful to deal with the non-linear threshold behaviour of some macroscopic tree-ring features like, e.g., light rings (Girardin et al. 2009).

Due to the more coincidental observation of wood anatomical features within wood anatomical or dendrochronological studies, little is still known about the occurrence of such features in economically less import and less studied tree species or about the susceptibility of regional ecotypes of widespread species for the formation of wood anatomical anomalies in response to extreme climatic events. Parallel investigations of trees planted in provenance trials may be useful in studying the genetic predisposition of different populations towards climatic extreme events and hence may help to select better-adapted species or provenances to make future forests more resilient towards climatic impact.

One big advantage of wood is that specific events can be reconstructed back in time, so specific tree-ring indicators help in reconstructing changes in the occurrence of pest infestations or fungal attack and provide useful information on ecosystem stability, climate change, and forest ecology. Since cracks and other wounds provide pathways for pathogens and since resource depletion is also weakening the defence of trees towards infestations, specific macroscopic tree-ring features may also be used as early warning signs for changing infection risks of forest trees. New categories of macroscopic anatomical features like, e.g., the distinctness of tree-ring boundaries (Tarelkin et al. 2016) may provide additional indicators useful for monitoring tree health under climatic regime shifts.

\section{ACKNOWLEDGEMENTS}

This study profited from discussions within the COST Action STReESS (COST-FP1106). Maaike De Ridder thanks the Federal Belgian Science Policy for funding on the BRAIN-project HERBAXYLAREDD.

\section{REFERENCES}

Abedini R, Clair B, Pourtahmasi K, Laurans F \& Arnould O. 2015. Cell wall thickening in developing tension wood of artificially bent poplar trees. IAWA J. 36: 44-57.

Aigner F. 1981. Bestandes- und Holzschäden durch Rissbildungen an Fichte. Allg. Forstz. 36: $720-722$.

Astrade L \& Bégin I. 1997. Tree-ring response of Populus tremula L. and Quercus robur L. to recent spring floods of the Sâone River, France. Ecoscience 4: 232-239.

Ballesteros JA, Stoffel M, Bodoque JM, Bollschweiler M, Hitz O \& Díez-Herrero A. 2010. Changes in wood anatomy in tree rings of Pinus pinaster Ait. following wounding by flash floods. Tree-Ring Research 66: 93-103. 
Bamber RK. 2001. A general theory for the origin of growth stresses in reaction wood: how trees stay upright. IAWA J. 22: 205-212.

Barrett DK. 1958. Cracking in the main stem of noble fir at Lethen, Nairnshire. Scott For. 12: 187-193.

Beeckman H. 2016. Wood anatomy and trait-based ecology. IAWA J. 37: 127-151.

Booker RE. 1994. Internal checking and collapse - which comes first? In: Proc. 4th IUFRO Wood Drying Conf.: Improving Wood Drying Technology: 133-140. Forest Research Institute, Rotorua, New Zealand, 9-13 August 1994.

Bräuning A. 2001. Climate history of the Tibetan Plateau during the last 1000 years derived from a network of Juniper chronologies. Dendrochronologia 19: 127-137.

Bräuning A. 2006. Tree-ring evidence of 'Little Ice Age' glacier advances in southern Tibet. The Holocene 16: 369-380.

Briffa KR, Jones PD, Schweingruber FH \& Osborn TJ. 1998. Influence of volcanic eruptions on northern hemisphere summer temperature over the last 600 years. Nature 393: 450-455.

Brüchert F \& Gardiner B. 2006. The effect of wind exposure on the tree aerial architecture and biomechanics of Sitka spruce (Picea sitchensis, Pinaceae). Amer. J. Bot. 93: 1512-1521.

Butler DR \& Sawyer CF. 2008. Dendrogeomorphology and high-magnitude snow avalanches: a review and case study. Natural Hazards and Earth System Sciences 8: 303-309.

Caspari CO \& Sachsse H. 1990. Rissschäden an Ficthe. Forst und Holz 45: 685-688.

Cherubini P, Schweingruber FH \& Forster T. 1997. Morphology and ecological significance of intra-annual radial cracks in living conifers. Trees 11:216-222.

Chhin S, Chumack K, Dahl T, David ET, Kurzeja P, Magruder M \& Telewski FW. 2013. Growthclimate relationships of Pinus strobus in the floodway versus terrace forest along the banks of the Red Cedar River, Michigan. Tree-Ring Research 69: 37-47.

Christiansen E, Krokene P, Berryman AA, Franceschi VR, Krekling T, Lieutier F, Lönneborg A \& Solheim H. 1999. Mechanical injury and fungal infection induce acquired resistance in Norway spruce. Tree Physiology 19: 399-403.

Ciais P, Reichstein M, Viovy , Granier A, Ogée J, Allard V, Aubinet N, et al. 2005. Europe-wide reduction in primary productivity caused by the heat and drought in 2003. Nature 437: 529-533.

Clair B, Alméras T, Yamamoto H, Okuyama T \& Sugiyama J. 2006. Mechanical behavior of cellulose microfibrils in tension wood, in relation with maturation stress generation. Biophysical J. 91: 1128-1135.

Clair B, Gril J, Baba KI, Thibaut B \& Sugiyama J. 2005. Precautions for the structural analysis of the gelatinous layer in tension wood. IAWA J. 26: 189-195.

Clair B \& Thibaut B. 2001. Shrinkage of the gelatinous layer of poplar and beech tension wood. IAWA J. 22: 121-131.

Cochard H \& Tyree MT. 1990. Xylem dysfunction in Quercus: vessel sizes, tyloses, cavitation and seasonal changes in embolism. Tree Physiology 6: 393-407.

Copini P. 2015. Markers inside wood - tree rings as archives of insect outbreaks, drift-sand dynamics, and spring flooding. PhD Thesis, Wageningen University. $159 \mathrm{pp}$.

Côté WA \& Day AC. 1965. Anatomy and ultrastructure of reaction wood. Cellular ultrastructure of woody plants. Syracuse Univ. Press. 603 pp.

Coutand C, Jeronimidis G, Chanson B \& Loup C. 2004. Comparison of mechanical properties of tension and opposite wood in Populus. Wood Sci. Technol. 38: 11-24.

Day WR \& Peace TR. 1934. The experimental production and the diagnosis of frost injury on forest trees. Oxford Forestry Mem. 16: 1-60.

De Micco V, Balzano A, Wheeler EA \& Baas P. 2016a. Tyloses and gums: a review of structure, function and occurrence of vessel occlusions. IAWA J. 37: 186-205. 
De Micco V, Battipaglia G, Cherubini P \& Aronne G. 2014. Comparing methods to analyse anatomical features of tree rings with and without intra-annual density fluctuations (IADFs). Dendrochronologia 32: 1-6.

De Micco V, Campelo F, De Luis M, Bräuning A, Grabner M, Battipaglia G \& Cherubini P. 2016b. Intra-annual density fluctuations in tree rings: how, when, where, and why? IAWA J. 37: 232-259.

De Ridder M, Trouet V, Van den Bulcke J, Hubau W, Van Acker J \& Beeckman H. 2013. A treering based comparison of Terminalia superba climate-growth relationships in West and Central Africa. Trees 27: 1225-1238.

Delwaide A, Filion L \& Payette S. 1991. Spatiotemporal distribution of light rings in subarctic black spruce, Quebec. Canad. J. For. Res. 21: 1828-1832.

Dittmar C, Fricke W \& Elling W. 2006. Impact of late frost events on radial growth of common beech (Fagus sylvatica L.) in Southern Germany. Europ. J. For. Res. 125: 249-259.

Donaldson LA, Grace J \& Downes GM. 2004. Within-tree variation in anatomical properties of compression wood in radiata pine. IAWA J. 25: 253-271.

Donges JF, Schleussner CF, Siegmund JF \& Donner RV. 2015. Coincidence analysis for quantifying statistical interrelationships between event time series - On the role of flood events as possible drivers of epidemic outbreaks. Physics and Society: arXiv:1508.03534.

Dy G \& Payette S. 2007. Frost hollows of the boreal forest as extreme environments for black spruce tree growth. Canad. J. For. Res. 37: 492-504.

Esper J, Büntgen U, Luterbacher J \& Krusic PJ. 2013. Testing the hypothesis of post-volcanic missing rings in temperature sensitive dendrochronological data. Dendrochronologica 31 : 216-222.

Evert RF. 2006. Esau's Plant Anatomy. Wiley-Interscience, Hoboken, NJ. 601 pp.

Fang CH, Clair B, Gril J \& Liu SQ. 2008. Growth stresses are highly controlled by the amount of G-layer in poplar tension wood. IAWA J. 29: 237-246.

Filion L, Payette S, Gauthier L \& Boutin Y. 1986. Light rings in subarctic conifers as a dendrochronological tool. Quaternary Research 26: 272-279.

Fisher JB \& Stevenson JW. 1981. Occurrence of reaction wood in branches of dicotyledons and its role in tree architecture. Bot. Gaz. 1: 82-95.

Fletcher JM. 1975. Relation of abnormal earlywood in oaks to dendrochronology and climatology. Nature 254: 506-507.

Fonti P, von Arx G, García-González I, Eilmann B, Sass-Klaassen U, Gärtner H \& Eckstein D. 2010. Studying global change through investigation of the plastic responses of xylem anatomy in tree rings. New Phytologist 185: 42-53.

Friedrich M, Kromer B, Spurk M, Hofmann J \& Kaiser KF. 1999. Paleo-environment and radiocarbon calibration as derived from Lateglacial/Early Holocene tree-ring chronologies. Quaternary International 61: 27-39.

Fritts HC. 1976. Tree rings and climate. Academic Press, London, New York, San Francisco. $576 \mathrm{pp}$.

Galvin S, Potito A \& Hickey K. 2014. Evaluating the dendroclimatological potential of Taxus baccata (yew) in southwest Ireland. Dendrochronologia 32: 144-152.

García-González I \& Eckstein D. 2003. Climatic signal of earlywood vessels of oak on a maritime site. Tree Physiology 23: 497-504.

García-González I, Souto-Herrero M \& Campelo F. 2016. Ring porosity and earlywood vessels: a review on extracting environmental information through time. IAWA J. 37: 295-314.

Gardiner B, Barnett J, Saranpää P \& Gril J. (eds.) 2014. The biology of reaction wood. Springer Series in Wood Sciences, Heidelberg. 274 pp. 
Gärtner H \& Heinrich I. 2009. The formation of traumatic rows of resin ducts in Larix decidua and Picea abies (Pinaceae) as a result of wounding experiments in the dormant season. IAWA J. 30: 199-215.

Gärtner H \& Heinrich I. 2013. Dendrogeomorphology. In: Elias SA (ed.), The Encyclopedia of Quaternary Sciencs 2: 91-103. Elsevier, Amsterdam.

Gärtner H, Lucchinetti S \& Schweingruber FH. 2014. New perspectives for wood anatomical analysis in dendrosciences: the GSL1-microtome. Dendrochronologia 32: 47-51.

Gindl W. 1999. Climatic significance of light rings in timberline spruce, Picea abies, Austrian alps. Arctic, Antarctic, and Alpine Research 31: 242-246.

Gindl W \& Grabner M. 2000. Characteristics of spruce [Picea abies (L.) Karst.] latewood formed under abnormally low temperatures. Holzforschung 54: 9-11.

Gindl W, Grabner M \& Wimmer R. 2000. The influence of temperature on latewood lignin content in treeline Norway spruce compared with maximum density and ring width. Trees 14: 409-414.

Girardin MP, Tardif JC, Epp B \& Conciatori F. 2009. Frequency of cool summers in interior North America over the past three centuries. Geophysical Research Letters 36, L07705; DOI: $10.1029 / 2009$ GL037242.

Glawenda M \& Koprowski M. 2012. Dendrochronological analysis of radial growth of western hemlock (Tsuga heterophylla Sarg.) from Western Pomerania (Dobrzany Forest District). Sylwan 156: 287-293.

Glerum C \& Farrar JL. 1966. Frost ring formation in the stems of some coniferous species. Canad. J. Bot. 44: 879-886.

Glock WS. 1951. Cambial frost injuries and multiple growth layers at Lubbock, Texas. Ecology 32: 28-36.

Grabner M, Cherubini P, Rozenberg P \& Hannrup B. 2006. Summer drought and low earlywood density induce intra-annual radial cracks in conifers. Scandinavian J. For. Res. 21: $151-157$.

Grabner M, Gierlinger N \& Wimmer R. 2001. Mechanism leading to intra-ring radial cracks in young spruce trees. In: Kaennel Dobbertin M \& Bräker OU (eds.), Tree rings and people: 204-205. International Conference on the Future of Dendrochronology, Davos, 22-26 September 2001. Abstracts. Swiss Federal Research Institute WSL, Birmensdorf.

Gurskaya MA. 2014. Temperature conditions of the formation of frost damages in conifer trees in the high latitudes of western Siberia. Biology Bull. 41: 187-196.

Hantemirov RM, Gorlanova LA \& Shiyatov SG. 2004. Extreme temperature events in summer in northwest Siberia since AD 742 inferred from tree rings. Palaeogeography, Palaeoclimatology, Palaeoecology 209: 155-164.

Hartig R. 1896. Innere Frostspalten. Forst. Naturw. Z. 5: 483-488.

Heinrich I, Gärtner H \& Monbaron M. 2007. Tension wood formed in Fagus sylvatica and Alnus glutinosa after simulated mass movement events. IAWA J. 28: 39-48.

Helinska-Raczkowska I. 1994. Variation of vessel lumen diameter in radial direction as an indication of the juvenile wood growth in oak (Quercus petraea Liebl). Ann. For. Sci. 51: 283-290.

Hetzer T, Bräuning A \& Leuschner H-H. 2014. High-resolution climatic analysis of wood anatomical features in Corsican pine from Corsica (France) using latewood tracheid profiles. Trees 28: 1279-1288.

Hogg EH, Hart M \& Lieffers VJ. 2002. White tree rings formed in trembling aspen saplings following experimental defoliation. Canad. J. For. Res. 32: 1929-1934.

Jaccard P. 1938. Exzentrisches Dickenwachstum und anatomisch-histologische Differenzierung des Holzes. Ber. Schweiz. Bot. Ges. 48: 491-537. 
Khishigjargal M, Dulamsuren C, Leuschner HH, Leuschner C \& Hauck M. 2014. Climate effects on inter- and intra-annual larch stemwood anomalies in the Mongolian forest-steppe. Acta Oecol. 55: 113-121.

Knuchel H. 1947. Holzfehler. Werner Classen, Zürich.

Koprowski M \& Duncker P. 2012. Tree ring width and wood density as the indicators of climatic factors and insect outbreaks affecting spruce growth. Ecological Indicators 23: 332-337.

Krause C, Gionest F, Morin H \& MacLean D. 2003. Temporal relations between defoliation caused by spruce budworm (Choristoneura fumiferana Clem.) and growth of balsam fir (Abies balsamea (L.) Mill.). Dendrochronologia 21: 23-31.

Krepkowski J, Bräuning A \& Gebrekirstos A. 2012. Growth dynamics and potential for crossdating and multi-century climate reconstruction of Podocarpus falcatus in Ethiopia. Dendrochronologia 30: 257-265.

Kübler H. 1983. Mechanism of frost crack formation in trees. A review and synthesis. Forest Sciences 29: 559-568.

Lakatos F \& Mirtchev S. 2014. Handbook of the major forest pests in Southeast Europe. FAO, ISBN 978-92-5-108580-6.

LaMarche VC. 1970. Frost-damage rings in subalpine conifers and their application to tree-ring dating problems. In: Smith JHG \& Worral J (eds.), Tree-ring analysis with special reference to Northwest America. Fac. Forest Bull. 7: 99-100. University of British Columbia, Vancouver.

LaMarcheVC \& Hirschboeck K. 1984. Frost rings in trees as records of major volcanic eruptions. Nature 307: 121-126.

Land A. 2014. Holzanatomische Veränderungen als Reaktion auf extreme Umweltereignisse in rezenten und subfossilen Eichen und deren Verifizierung im Experiment. PhD Thesis, Universität Hohenheim. 332 pp. http://opus.uni-hohenheim.de/volltexte/2014/1029/

Land A, Schönbein J \& Friedrich M. 2015. Extreme climate events identified by wood-anatomical features from the river Main valley (Germany) - a case study for 3000 to 2000 BC. In: Meller H, Arz HW, Jung R \& Risch R (eds.), 2200 BC - A climatic breakdown as a cause for the collapse of the old world? Tagungen des Landesmuseums für Vorgeschichte 13: 595-602.

Leuschner HH \& Schweingruber FH. 1996. Dendroökologische Klassifizierung und Auswertung häufig auftretender intraannueller holzanatomischer Merkmale bei Eichen und Kiefern. Dendrochronologia 14: 275-285.

Liang C, Filion L \& Cournoyer L. 1997. Wood structure of biotically and climatically induced light rings in eastern larch (Larix laricina). Canad. J. For. Res. 27: 1538-1547.

Liang E \& Eckstein D. 2006. Light rings in Chinese pine (Pinus tabulaeformis) in semiarid areas of north China and their palaeo-climatological potential. New Phytologist 171: 783-791.

Lorimer CG, Dahir SE \& Singer MT. 1999. Frequency of partial and missing rings in Acer saccharum in relation to canopy position and growth rate. Plant Ecology 143: 189-202.

Lowe J. 1897. The Yew trees of Great Britain and Ireland. Macmillan, London.

Mann ME, Fuentes JD \& Rutherford S. 2012. Underestimation of volcanic cooling in tree-ring based reconstruction of hemispheric temperatures. Nature Geoscience 5: 202-205. 3

Martin D, Tholl D, Gershenzon J \& Bohlmann J. 2002. Methyl jasmonate induces traumatic resin ducts, terpenoids resin biosynthesis, and terpenoids accumulation in developing xylem of Norway spruce stems. Plant Physiology 129: 1003-1018.

Mayr S, Wieser G \& Bauer H. 2006. Xylem temperatures during winter in conifers at the altime timberline. Agr. Forest Meteorology 137: 81-88.

McDougall KL, Brookhouse MT \& Broome LS. 2012. Dendroclimatological investigation of mainland Australia's only alpine conifer, Podocarpus lawrencei Hook.f. Dendrochronologia 30: $1-9$. 
McDowell N, Pockman WT, Allen CD, Breshears DD, Cobb N, Kolb T, Plaut J, Sperry J, West A, Williams DG \& Yepez EA. 2008. Mechanisms of plant survival and mortality during drought: why do some plants survive while others succumb to drought? New Phytol. 178: 719-739.

Morita MT \& Tasaka M. 2004. Gravity sensing and signaling. Current Opinion in Plant Biology 7: 712-718.

Nagy NE, Franceschi VR, Solheim H, Krokene P \& Christiansen E. 2000. Wound-induced traumatic resin duct development in stems of Norway spruce (Pinaceae): Anatomy and cytochemical traits. Amer. J. Bot. 87: 302-313.

Nördlinger H. 1878. Trockenrisse (falsche Frostrisse) an der Fichte. Auch ein Grund der Rothfäule. Cbl. Ges. Forstw. 4: 281-284.

Novak K, De Luis M, Čufar K \& Raventós J. 2011. Frequency and variability of missing tree rings along the stems of Pinus halepensis and Pinus pinea from a semiarid site in SE Spain. Journal of Arid Environments 75: 494-498.

Novak K, De Luis M, Gričar J, Prislan P, Merela M, Smith KT \& Čufar K. 2016. Missing and dark rings associated with drought in Pinus halepensis. IAWA J. 37: 260-274.

Olano JM, Arzac A, García-Cervigón A, von Arx G \& Rozas V. 2013. New star on the stage: amount of ray parenchyma in tree rings shows a link to climate. New Phytol. 198: 486-495.

Ossenbruggen PJ, Peters MA \& Shigo AL. 1986. Potential failure of a decayed tree under wind loading. Wood Fiber Science 18: 168-186.

Panayotov M. 2007. Influence of ecological factors on the growth of the tree species from Pinaceae family at the Bulgarian treeline. University of Forestry, Sofia.

Panayotov M \& Yurukov S. 2007. Tree ring chronology from Pinus peuce in Pirin Mts and the possibilities to use it for climate analysis. Phytologia Balcanica 13: 313-320.

Panayotov M, Zafirov N \& Cherubini P. 2013. Fingerprints of extreme climate events in Pinus sylvestris tree rings from Bulgaria. Trees 27: 211-227.

Paredes-Villanueva K, Sanchez-Salguero R, Manzanedo RD, Sopepi RQ, Palacios G \& NavarroCerrillo RM. 2013. Growth rate and climatic response of Machaerium scleroxylon in a dry tropical forest in southeastern Santa Cruz, Bolivia. Tree-Ring Research 69: 63-79.

Pellizzari E, Pivodori M \& Carrer M.2014. Winter precipitation effect in mid-latitude temperaturelimited environment: the case of common juniper at high elevation in the Alps. Environmen-tal Research Letters 9: 104021. Pdf reprint.

Peters MA, Ossenbruggen PA \& Shigo AL. 1985. Cracking and failure behavior models of defective balsam fir trees. Holzforschung 39: 125-135.

Piermattei A, Crivellaro A, Carrer M \& Urbinati C. 2015. The "blue ring": anatomy and formation hypothesis of a new tree-ring anomaly in conifers. Trees 29: 613-620.

Pohl KA, Hadley KS \& Arabas KB. 2006. Decoupling tree-ring signatures of climate variation, fire, and insect outbreaks in Central Oregon. Tree-Ring Research 62: 37-50.

Pourtahmasi K, Lotfiomran N, Bräuning A \& Parsapajouh D. 2011. Variations of tree growth and vessel characteristics of Fagus orientalis along an altitudinal gradient in the Caspian Forests, northern Iran. IAWA J. 32: 461-473.

Priya PB \& Bhat KM. 1998. False ring formation in teak (Tectona grandis L.f.) and the influence of environmental factors. Forest Ecology and Management 108: 215-222.

Raven PH, Evert RF \& Eichhorn SE. 1999. Biology of plants. Ed. 6. Freeman \& Co./Worth Publishers, New York, NY, USA.

Richter HG, Grosser D, Heinz I \& Gasson PE. 2004. IAWA list of microscopic features for softwood identification. IAWA J. 25: 1-70.

Robson JRM, Conciatori F, Tardif JC \& Knowles K. 2015. Tree-ring response of Jack pine and Scots pine to budworm defoliation in Central Canada. Forest Ecology and Management 347: 83-95. 
Rossi S, Deslauriers A, Anfodillo T \& Carraro V. 2008. Evidence of threshold temperatures for xylogenesis in conifers at high altitudes. Oecologia 152: 1-12.

Rozas V, Pérez-de-Lis G, García-González I \& Arévalo JR. 2011. Constrasting effects of wildfire and climate on radial growth of Pinus canariensis on windward and leeward slopes on Tenerife, Canary Islands. Trees 25: 895-905.

Schneider L \& Gärtner H. 2013. The advantage of using a starch based non-Newtonian fluid to prepare micro sections. Dendrochronologia 31: 175-178.

Scholz A, Klepsch M, Karimi Z \& Jansen S. 2013. How to quantify conduits in wood? Frontiers in Plant Science 4. DOI: 10.3389/fpls.2013.00056.

Schweingruber FH. 1996. Tree rings and environment: dendroecology. Swiss Federal Institute for Forest, Snow and Landscape Research, Birmensdorf, Paul Haupt Publishers, Berne, Stuttgart, Vienna. 609 pp.

Schweingruber FH. 2007. Wood structure and environment. Springer Science \& Business Media, Heidelberg. 279 pp.

Schweingruber FH, Eckstein D, Serre-Bachet F \& Bräker OU. 1990. Identification, presentation and interpretation of event years and pointer years in dendrochronology. Dendrochronologia 8: 9-38.

Scurfield G. 1973. Reaction wood: its structure and function. Science 179 (4074): 647-655.

Sheue CR, Chang HC, Yang YP, Liu HY, Chesson P \& Hsu FH. 2014. A new classification of marginal resin ducts improves understanding of Hard pine (Pinaceae) diversity in Taiwan. Flora-Morphology, Distribution, Functional Ecology of Plants 209: 414-425.

Sinnott EW. 1952. Reaction wood and the regulation of tree form. Amer. J. Bot. 39: 69-78.

Sorauer P. 1922. Manual of plant diseases. I. Non-parasitic diseases. Ed. 3. Transl. from German by F. Dorrance. Record Press, Wilkes-Barre, Penna.

Sousa VB, Cardoso S, Quilho T \& Pereira H. 2012. Growth rate and ring width variability of teak, Tectona grandis (Verbenaceae) in an unmanaged forest in East Timor. Rev. Biol. Trop. 60: 483-494.

St.George S, Ault TR \& Torbenson MCA. 2013. The rarity of absent growth rings in Northern Hemisphere forests outside the American Southwest. Geophys. Res. Lett. 40: 3727-3731.

St.George S, Nielsen E, Conciatori F \& Tardif J. 2002. Trends in Quercus macrocarpa vessel areas and their implications for tree-ring paleoflood studies. Tree-Ring Bull. 58: 3-10.

Stahle D. 1990. The tree-ring record of false spring in the southcentral USA. Dissertation, Arizona State University.

Sutton A \& Tardif JC. 2005. Distribution and anatomical characteristics of white rings in Populus tremuloides. IAWA J. 26: 221-238.

Swetnam TW \& Lynch AN. 1989. A tree-ring reconstruction of western spruce budworm history in the southern Rocky Mountains, For. Sci. 35: 962-986.

Szeicz JM. 1996. White spruce light rings in northwestern Canada. Arctic and Alpine Research 28: $184-189$.

Tardif JC, Girardin MP \& Conciatori F. 2011. Light rings as bioindicators of climate change in Interior North America. Global and Planetary Change 79: 134-144.

Tarelkin Y, Delvaux C, De Ridder M, De Cannière C \& Beeckman H. 2016. Tree-ring distinctness based on IAWA's definition: variability and consequences for trait analysis. IAWA J. 37: 275-294.

Tasaka M, Kato T \& Fukaki H. 1999. The endodermis and shoot gravitropism. Trends in Plant Science 4: 103-107.

Timell TE. 1986. Compression wood in gymnosperms (3 vols.). Springer, Berlin. 2210 pp.

von Arx G \& Carrer M. 2014. ROXAS - A new tool to build centuries-long tracheid-lumen chronologies in conifers. Dendrochronologia 32: 290-293. 
von Arx G, C. Kueffer \& P. Fonti. 2013. Quantifying plasticity in vessel grouping - added value from the image analysis tool ROXAS. IAWA J. 34: 433-445.

Waito J, Conciatori F \& Tardif JC. 2013. Frost rings and white earlywood rings in Picea mariana trees from the boreal plains, Central Canada. IAWA J. 34: 71-87.

Wang L, Payette S \& Bégin Y. 2000. A quantitative definition of light rings in black spruce (Picea mariana) at the Arctic treeline in northern Quebec, Canada. Arctic, Antarctic, and Alpine Research 32: 324-330.

Wang L, Payette S \& Bégin Y. 2002. Relationships between anatomical and densitometric characteristics of black spruce and summer temperature at tree line in northern Quebec. Canad. J. For. Res. 32: 477-486.

Wardrop AB. 1965. The formation and function of reaction wood. In: Côté WA (ed.), Cellular ultrastructure of woody plants: 373-390). Syracuse University Press, New York.

Wardrop AB \& Dadswell HE. 1955. The nature of reaction wood. IV. Variations in cell wall organization of tension wood fibres. Austral. J. Bot. 3: 177-189.

Weber UM. 1997. Dendroecological reconstruction of larch budmoth (Zeiraphera diniana) outbreaks in two central alpine valleys of Switzerland from 1470-1990. Trees 11: 277-290.

Werf GW van der, Sass-Klaassen U \& Mohren GMJ. 2007. The impact of the 2003 summer drought on the intra-annual growth pattern of beech (Fagus sylvatica L.) and oak (Quercus robur L.) on a dry site in the Netherlands. Dendrochronologia 25: 103-112.

Westing AH. 1965. Formation and function of compression wood in gymnosperms. The Botanical Review 31: 381-480.

Wiedenhoeft AC \& Miller RB. 2002. Brief comments on the nomenclature of softwood axial resin canals and their associated cells. IAWA J. 23: 299-303.

Wilmking M, Hallinger M, Van Bogaert R, Kyncl T, Babst F, Hahne W, Juday GP, De Luis M, Novak K \& Völlm C. 2012. Continuously missing outer rings in woody plants at their distributional margins. Dendrochronologia 30: 213-222.

Wils THG, Sass-Klaassen U, Eshetu Z, Bräuning A, Gebrekirstos A, Couralet C, Robertson I, Touchan R, Koprowski M, Conway D, Briffa KR \& Beeckman H. 2011. Dendrochronology in the dry tropics: the Ethiopian case. Trees 25: 345-354.

Wilson BF \& Archer RR. 1977. Reaction wood: induction and mechanical action. Annual Review of Plant Physiology 28: 23-43.

Wimmer R. 2002. Wood anatomical features in tree-rings as indicators of environmental change. Dendrochronologia. 20: 21-36.

Wistuba M, Malik I, Gärtner H, Kojs P \& Owczarek P. 2013. Application of eccentric growth of trees as a tool for landslide analyses: the example of Picea abies Karst. in the Carpathian and Sudeten Mountains (Central Europe). Catena 111: 41-55.

Worbes M. 2002. One hundred years of tree-ring research in the tropics - a brief history and an outlook to future challenges. Dendrochronologia 20: 217-231.

Yamaguchi DK, Filion L \& Savage M. 1993. Relationship of temperature and light ring formation at subarctic treeline and implications for climate reconstruction. Quaternary Research 39: $256-262$.

Yamamoto F. 1992. Effects of depth of flooding on growth and anatomy of stems and knee roots of Taxodium distichum. IAWA Bull. n.s. 13: 93-104.

Accepted: 8 April 2016 